\title{
Minerals in the future of Europe
}

\author{
Manuel Regueiro ${ }^{1}$ (1) $\cdot$ Antonio Alonso-Jimenez ${ }^{1,2}$
}

Received: 12 June 2020 / Accepted: 10 February 2021 / Published online: 9 March 2021

(C) The Author(s), under exclusive licence to Springer-Verlag GmbH Germany, part of Springer Nature 2021

\begin{abstract}
This paper deals with the future of mining in Europe but in the framework of a global pandemic. We have analysed the various prognosis of global growth trends and the future of mining in Europe, on the basis of the known statistical data of what has happened so far. Several case studies are included, and a proposal of a strong EU reaction to really be successful in the plans designed when the Raw Material Initiative was planned is suggested. The incredible mining potential of the EU as well as its technological leadership is here presented to demonstrate that, if politically supported, these can bring back Europe to the leading role in mining it had in the past.
\end{abstract}

Keywords EU · Mining · Production · Resources potential · GDP · Global trends · Jevons paradox · EU Mining Agency · COVID-19

\section{Introduction}

In a recent paper (Regueiro and Espi 2019), we concluded "To sum up it is clear that mining will not disappear and primary extraction will continue to grow in line with GDP growth, but technology will be a key factor in this future, and it will become increasingly important to better understand supply chains and consumer preferences."

As we were writing this paper, the biggest pandemic since the 1918 epidemic of what was wrongly called the Spanish Flue stroke the World. We are now confined to our homes and we have seen the most important global industrial halt since 2WW.

If an observer was to write about the future of any industry in February 2020, the conclusions could have been similar to what we said in 2019. Suddenly, the world halted, and globally, the oil and gas price drastically dropped as consumption stopped. There is obviously a direct correlation between GDP

Manuel Regueiro

m.regueiro@igme.es

Antonio Alonso-Jimenez

a.alonso@igme.es

1 Instituto Geológico y Minero de España (Gelogical Survey of Spain), Rios Rosas, 23, 28003 Madrid, Spain

2 Universidad Politécnica de Madrid, Rios Rosas, 21, 28003 Madrid, Spain growth and mining. Thus, as the world prepares to a severe drop in GDP, we must conclude that mining will suffer also a general drop. But we are seeing a very curious effect of the national isolation caused by the closure of frontiers. As imports of many minerals through ports stopped, many industries are looking for a national supply; then for some commodities, there is an increase in national production, and, at the same time, some exporting countries will suffer a severe drop in exports to Europa. Since Europe was a main global mineral importer, we might be seeing, during some months, an increase of the European mineral production for internal use, a reduction of imports from outside Europe and thus an improvement in the balance of payments in this sector.

\section{Global trends and scenarios before COVID19}

\section{World Bank}

The World Bank (World Bank (2020) forecasts a sharp drop in GPD globally in 2020 and a $-8 \%$ in global growth in 2020 (Figs. 1 and 2). Obviously, the mineral resources industrial sector will suffer parallel drops.

Global mining was expected to behave (Fig. 3; Ericsson, M.; Löf, O. \& Löf, A. RMG Consulting (2021)) with a rising production trend in the six resource-rich developing countries, a stable situation in current production leaders (Australia, Canada, China and Russia) and a stable drop in the EU. In 


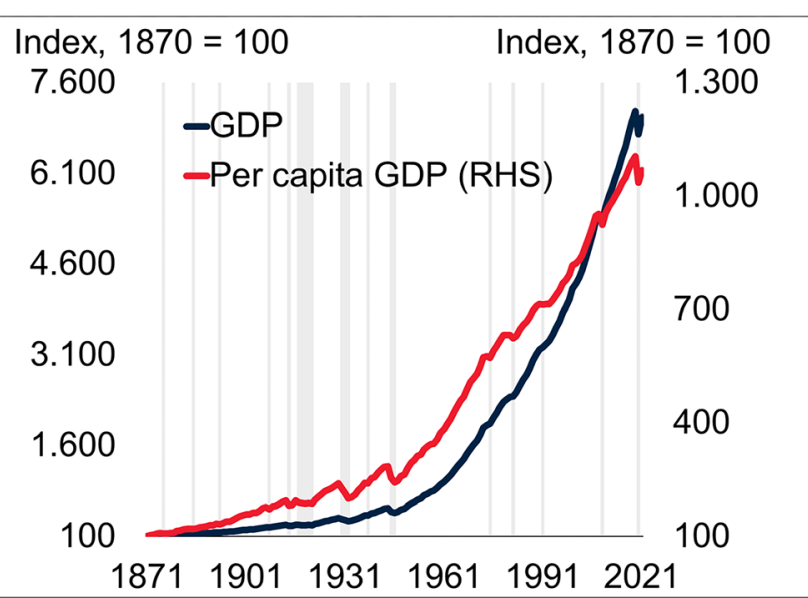

Fig. 1 GPD trends. Source: Bolt et al. (2018); Kose, Sugawara, and Terrones (2019, 2020); (World Bank 2020)

fact, Europe accounted for more than $50 \%$ of global mineral production in 1900 , but this share had fallen to under $5 \%$ by 2018. EU's mineral production is accounted for by a handful of Member States (Farooki et al. 2018). Poland accounts for $56 \%$ of EU's copper production, Sweden accounts for $90 \%$ of iron ore production and Greece and Finland each account for near one half of nickel production. Sweden accounts for $43 \%$ and Ireland for $32 \%$ of EU lead and zinc production, respectively.

\section{FORAM project}

The project Foram (Towards a World Forum on Raw Materials. FORAM Project 2017) suggested according to Freedonia (2016) that in construction materials, the global demand was going to be 51,000 Mt in 2019 (compared with $48,000 \mathrm{Mt}$ in 2015), and China was expected to remain by far the largest national consumer of aggregates in 2019. The forecast seems to have been right if we look at the figures published by GAIN-Global Aggregates Information Network

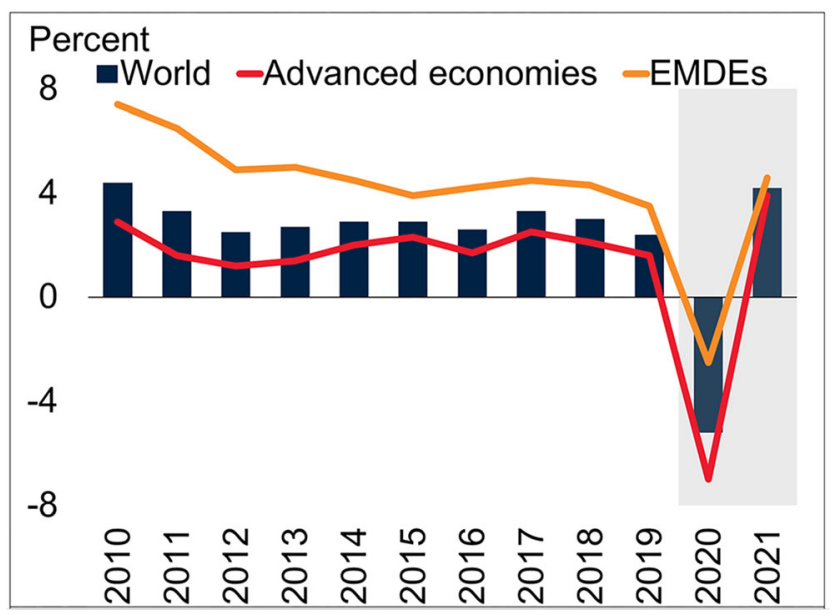

Fig. 2 Global growth. Source: World Bank (2020)
(GAIN 2020). These same projects suggested that on a longterm basis, the global demand for metals was expected to remain robust (e.g. PGMs, tin), and even in some cases (e.g. iron, bauxite, nickel, lithium or cobalt) would keep increasing, despite short-term downturns.

\section{INTRAW project}

The EU project INTRAW (INTRAW 2020) suggested three potential scenarios for the raw materials in 2050:

\section{Scenario 1: sustainability alliance}

In 2050, the circular economy has become the norm in the big advanced economies; a new generation of political leaders has pushed forward a series of reforms that focus on increasing sustainability not only in the raw materials industry. Almost every product is produced in an environmentally friendly way with the aid of green technologies. Decision makers are under pressure to meet public demands for more environmentally friendly solutions and policies.

\section{Scenario 2: unlimited trade}

In 2050, the world of raw materials has experienced steady growth, mainly due to ever-growing consumption. International cooperation and dialogue have created new opportunities to produce and trade raw materials. Access to capital has led to industry integration, technology development and productivity improvements alike.

\section{Scenario 3: national walls}

In 2050, the world of raw materials stagnated as social and demographic pressures triggered a long period of economic standstill, which eventually lead to a rise of protectionist measures. The absence of leadership and insufficient political engagement will not help to improve the situation. Each country fights for its own agenda. There is little progress in mining practices as reforms have stalled and private investments are low.

Obviously, there are scenarios that are similar: global fragmentation equals national walls, unlimited trade equals resource abundance, but a world of two speeds and sustainability alliance are two potential scenarios that do not mach.

The latest published prognosis of the future of mining globally is the document of the World Bank titled "Minerals for Climate Action: The Mineral Intensity of the Clean Energy Transition" (Hund et al. 2020)

The conclusions of this report were:

1. Rising overall demand for minerals. The demands for base and niche minerals to help build clean energy 


\section{Locus of world mining 1850-2030 metals and industrial minerals (per cent of value of total world production excluding coal)}

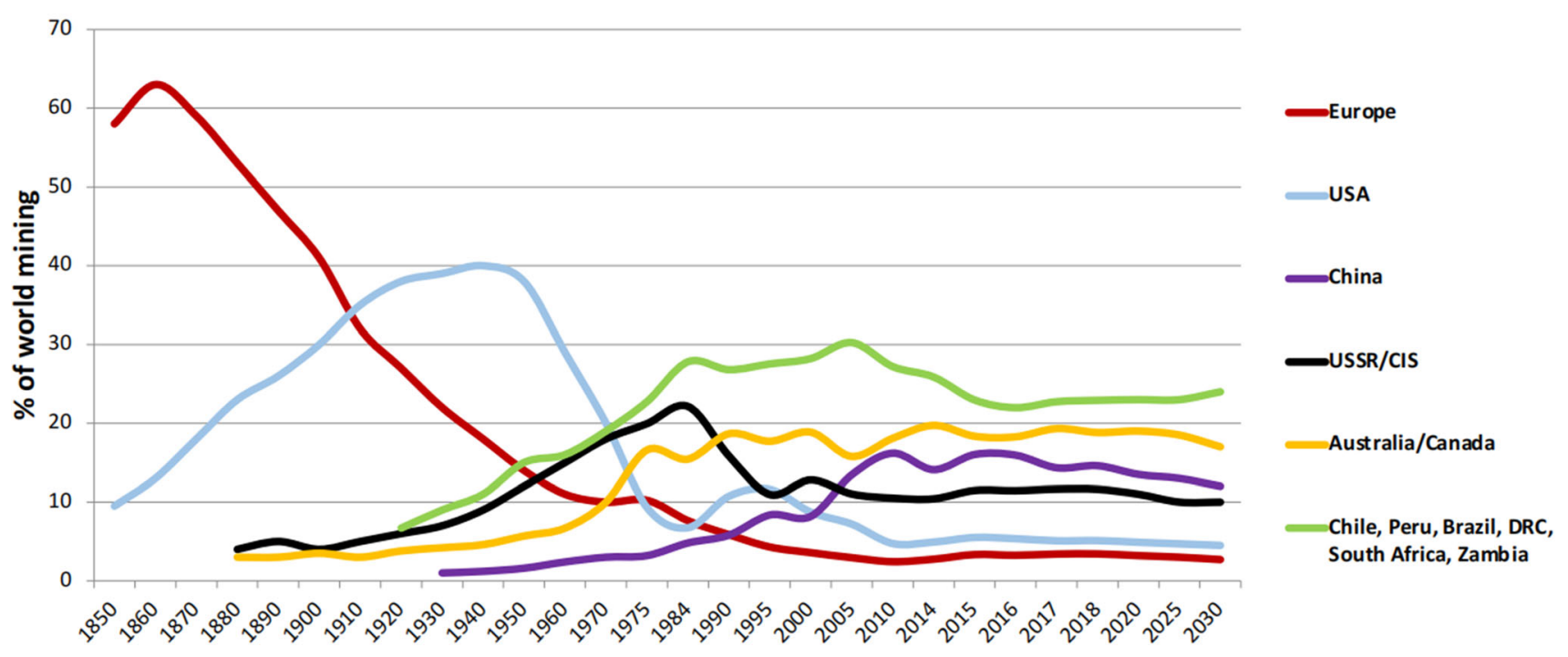

Source: RMG Consulting 2021

Fig. 3 World mining trends 1850-2030

technologies are expected to rise substantially up to 2050 , increasing in both absolute and percentage terms from 2018 production levels. Based on the model presented in that report, large relative increases in demand of up to nearly $500 \%$ are estimated for certain minerals, especially those concentrated in energy storage technologies, such as lithium, graphite and cobalt (Table 1).

2. Mineral demand vulnerability and risks. Meeting the challenge of large-scale deployment of renewable energy requires the steady availability of a variety of key minerals as well as stable prices and minimal market disruptions. This is particularly true in developing countries that need to deliver on SDG 7, "access to affordable, reliable, sustainable and modern energy for all." The demand risk matrix calculated in the report provides an overview of how 17 minerals identified as key to the low-carbon transition are impacted by different demand profiles:

a. Medium-impact minerals, such as titanium and neodymium, are still affected by demand increases and may still play an important role in the clean energy transition.

b. High-impact minerals, such as graphite, lithium and cobalt, will, under a 2DS, need to increase their production significantly, up to nearly $500 \%$ by 2050 from 2018 levels. c. High-impact, cross-cutting minerals, such as aluminium, are critical not only because their demand does not depend on one specific technology, but also because they are needed in higher quantities across a wide variety of energy technologies.

d. Cross-cutting minerals such as copper, future demand from clean energy technologies may not represent a large portion of current production levels.

3. Role of recycling and reuse. Recycling, reuse and refurbishment have important roles in limiting and meeting future demand for minerals for clean energy.

4. Emission mitigation and reduction opportunities. While deploying renewable energy is one of the most effective ways to decarbonize the electricity sector, the mineral intensity of clean energy technologies must be addressed.

But the report also includes a chapter about the Risks Beyond the Model, because two crucial areas, supply and wider environmental and social risks, are not covered, but they are important in understanding the wider context of the report.

\section{World Economic Forum}

The World Economic Forum (WEF) (World Economic Forum, in collaboration with Boston Consulting Group. 
Table 12018 Mineral Production and 2050 Projected Annual Demand from Energy Technologies. Source: Hund et al. (2020)

\begin{tabular}{llll}
\hline Mineral & $\begin{array}{l}2018 \text { annual production } \\
\text { (tons, thousands) }\end{array}$ & $\begin{array}{l}2050 \text { projected annual demand from energy } \\
\text { technologies (tons, thousands) }\end{array}$ & $\begin{array}{l}2050 \text { projected annual demand from energy technologies as } \\
\text { percent of 2018 annual production }\end{array}$ \\
\hline Aluminium & 60,000 & 5583 & $9 \%$ \\
Chromium & 36,000 & 366 & $1 \%$ \\
Cobalt & 140 & 644 & $460 \%$ \\
Copper & 21,000 & 1378 & $7 \%$ \\
Graphite & 930 & 4590 & $494 \%$ \\
Indium & 0.75 & 1.73 & $231 \%$ \\
Iron & $1,200,000$ & 7584 & $1 \%$ \\
Lead & 4400 & 7.81 & $18 \%$ \\
Lithium & 85 & 415 & $488 \%$ \\
Manganese & 18,000 & 694 & $4 \%$ \\
Molybdenum & 300 & 33 & $11 \%$ \\
Neodymium & 23 & 8.4 & $37 \%$ \\
Nickel & 2300 & 2268 & $99 \%$ \\
Silver & 27 & 15 & $56 \%$ \\
Titanium & 6100 & 3.44 & $0 \%$ \\
Vanadium & 73 & 138 & $189 \%$ \\
\hline
\end{tabular}

2015), in its forecast of the future of mining for 2050, assumed a refined perspective of three potential scenarios:

1. A world of two speeds: Emergence of two (or more) groups of countries which are moving at widely differing speeds. One group, the "sustainable forerunners", is advancing rapidly towards a circular use of commodities and metals, while the other, the "mineral dependents" has deliberately chosen a slower pace.

2. Resource abundance. In the scenario, there is no scarcity of materials. This is due to technological changes that lead to increased metal production.

3. Global fragmentation. This scenario assumes an increased competition for resources by inability to match supply and demand. Higher population growth can be coupled with slower growth. Resources, including minerals, water, food, and others, deplete much faster than expected or are not traded sufficiently. At the same time, demand for commodities and metals cannot be fulfilled.

In these potential scenarios, mining in the World in 2050, according to the WEF, will probably:

(a) Be a more sustainable consumption in a more sustainable world.

(b) Resources will last longer while increased reuse and recycling drive a more circular economy. Such a trend will need appropriate infrastructure, regulation and legislation, and competitive cost economics. (c) Mining will not disappear; primary extraction will continue to grow in line with GDP growth. Pressure to realize scale effects and cost efficiency will remain in the foreseeable future together with a strong demand for environmentally and socially responsible actions.

(d) Metals will not disappear; metal companies will act as a liaison between commodity producers and end industries.

(e) Technology will be the key, and it will become increasingly important to better understand supply chains and consumer preferences.

(f) The evolution of the circular economy will be governed by many external factors within and beyond the mining and metal industry. But industry will be the main leader of circularity.

\section{European mining production: the statistics clash}

According to Federal Ministry of Industry Agriculture and Regions Ministry of Austria (2020), mining production in Europe has been steadily decreasing in the last few years (Fig. 4). The latest available figure is $1417 \mathrm{Mt}$ in 2018.

But these figures refer exclusively to iron and ferroalloy metals (iron $\mathrm{Fe} \mathrm{t}$, chromium $\mathrm{Cr}_{2} \mathrm{O}_{3} \mathrm{t}$, cobalt $\mathrm{Co} \mathrm{t}$, manganese $\mathrm{Mn} \mathrm{t}$, molybdenum Mo t, nickel Ni t, niobium $\mathrm{Nb}_{2} \mathrm{O}_{5} \mathrm{t}$, tantalum $\mathrm{Ta}_{2} \mathrm{O}_{5} \mathrm{t}$, titanium $\mathrm{TiO}_{2} \mathrm{t}$, tungsten $\mathrm{W} \mathrm{t}$, vanadium $\mathrm{Vt}$ ), non-ferrous metals (aluminium Al primary 


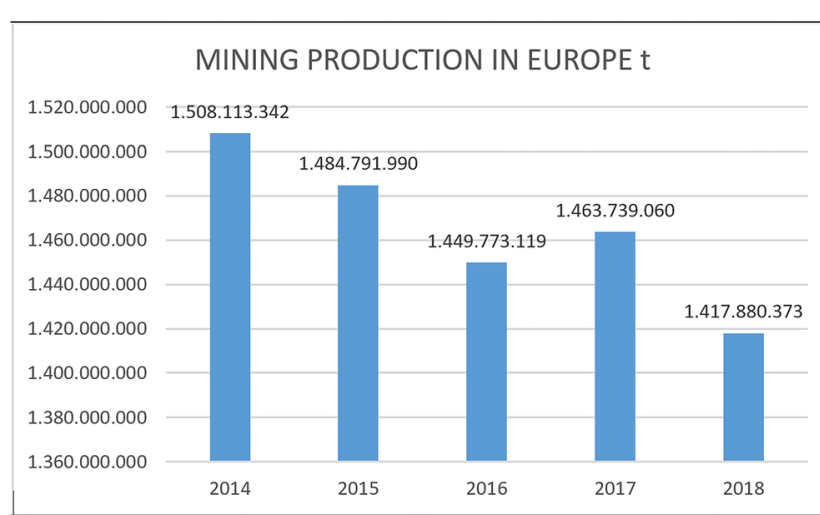

Fig. 4 Mining production of Europe (t). Source: [2]

$\mathrm{t}$, antimony $\mathrm{Sb} \mathrm{t}$, arsenic $\mathrm{As}_{2} \mathrm{O}_{3} \mathrm{t}$, bauxite crude ore $\mathrm{t}$, beryllium conc. $\mathrm{t}$, bismuth $\mathrm{Bi} \mathrm{t}$, cadmium $\mathrm{Cd} t$, copper $\mathrm{Cu}$ $\mathrm{t}$, gallium $\mathrm{Ga} t$, germanium Ge $\mathrm{t}$, indium $\mathrm{In} \mathrm{t}$, lead $\mathrm{Pb} \mathrm{t}$, lithium $\mathrm{Li}_{2} \mathrm{O}$ t, mercury $\mathrm{Hg}$ t, rare Earth minerals REO t, rhenium Re kg, selenium Se t, tellurium Te t, tin Sn t, zinc $\mathrm{Zn} \mathrm{t}$ ), precious metals (gold Au kg, palladium Pd kg, platinum $\mathrm{Pt} \mathrm{kg}$, rhodium $\mathrm{Rh} \mathrm{kg}$, silver $\mathrm{Ag} \mathrm{kg}$ ), industrial minerals (asbestos $t$, barite $t$, bentonite $t$, boron minerals $t$, diamonds (Gem) ct diamonds (Ind) ct, diatomite t, feldspar $t$, fluorspar $t$, graphite $t$, gypsum and anhydrite $t$ kaolin (China-Clay) $t$, magnesite $t$, perlite $t$, phosphates $\mathrm{P}_{2} \mathrm{O}_{5} \mathrm{t}$, potash $\mathrm{K}_{2} \mathrm{O}$ t, salt (rock salt, brines, marine salt) $t$, sulphur (elemental and industrial sulphur) $t$, talc, steatite and pyrophyllite $t$, vermiculite $t$, zircon conc. $t$ ) and mineral fuels (steam coal (incl. anthracite, bituminous and subbituminous coal) $t$, coking coal $t$, lignite $t$, natural gas Mio $\mathrm{m}^{3}$, oil sands crude $\mathrm{t}$, oil shales $\mathrm{t}$, petroleum crude $\mathrm{t}$, uranium $\mathrm{U}_{3} \mathrm{O}_{8} \mathrm{t}$ ), which means it does not include construction materials, an important mining sector in Europe and everywhere.

Unfortunately, the production of fossil fuels of Europe (in $t$ of oil equivalent) according to the 68th edition of the BP Statistical Review of World Energy 2019 (British Petroleum 2019), was in 2018227 Mt (Fig. 5). This

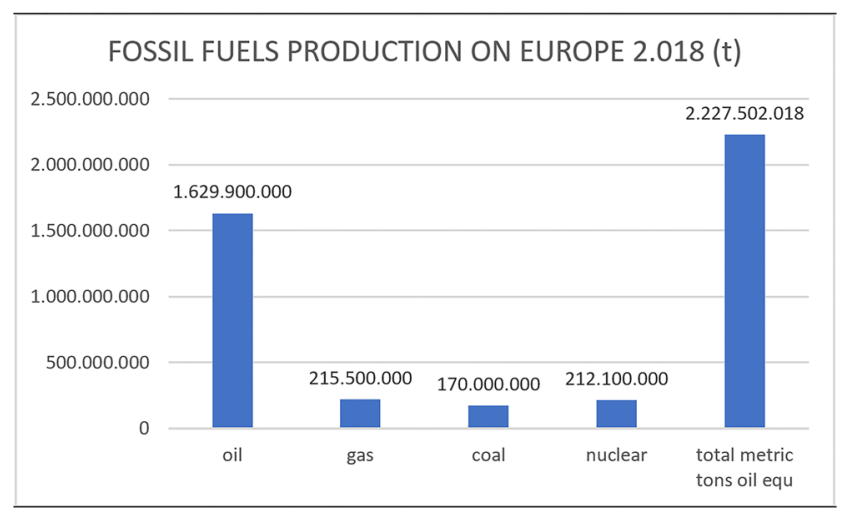

Fig. 5 Fossil fuel production of Europe 2018 ( $t$ of oil equivalents). Source: [3] means that either the WMD stats are wrong or BP stats are wrong.

Aside from those sources, there is no way of knowing the current European production of minerals. No institution or EU project produces updated statistics, so we have to look for prognosis from other sources.

The project (MIN-GUIDE 2019) (part of its results can be found in the Raw Materials Information System RMIS (https://rmis.jrc.ec.europa.eu/?page=rmkg) $($ European Commission 2020b) compiled the most recent European disaggregated production data, which can be found in Table 2 (for 2017).

According to that review, the raw material added value in the EU economy for that year was > $1.300 \mathrm{M} €$, the production value of EU domestic non-energy mining of raw materials (mainly construction minerals) was 45,000 $\mathrm{M} €$ and the direct employment was around 500,000 (aggregates alone amount to 200,000 ) whilst the indirect employment (downstream industries) reached circa 30 million people. In Europe in 2017, there were 60,000 non-energy mining operations (about 26,000 alone were aggregates), with a total production run-of-mine circa $4000 \mathrm{Mt} /$ year (aggregates alone produce $2700 \mathrm{Mt} /$ year) and the potential total extracted material could reach 10,000 $\mathrm{Mt} / \mathrm{year}$. Thus, the per capita consumption of non-energy raw materials in Europe (DMC) was estimated in $10 \mathrm{t}$ (aggregates alone are $5 \mathrm{t}$ ) and the non-energy mineral raw material consumption in Europe in 2017 was circa 5115 Mt. Well away from the $2227 \mathrm{Mt}$ - including energy minerals — stated by the Austrian Ministry. If we include the energy minerals from BP data (converting the TOE to TCE), we would have to conclude that the total mineral production of Europe in 2017 was circa $8297 \mathrm{Mt}$ of which $61 \%$ are non-energy products and 39\% energy minerals.

\section{Resourcing Europe}

Europe can boast of having a high tech mining industry and also of being self-sufficient in the production of some industrial minerals, being a world class producer of magnesite, gypsum, specialty clays or kaolin. But European mineral resources are insufficient in other cases, and this results in a very high dependence of extra-community sources such as China. The EU has also valuable deposits of copper (Poland, Iberian Copper Belt, Bulgaria, Sweden), zinc and lead (Sweden, Ireland, Poland) and even some CRMs such as tungsten deposits copper, zinc and silver as well as an immense array of potential future geological deposits of many minerals such as the recently discovered lithium deposits in the Czech Republic, Serbia, Portugal and Spain and the European mineral potential for metallic and non-metallic ores included in Fig. 6. 
Table 2 Non-energy mineral production and production value of Europe (2017). Sources: European Aggregate Association (Union Européenne des Producteurs de Granulats 2020), IMA Europe (Industrial Minerals Association-Europe 2020), EuroRoc (European and International Federation of Natural Stone Industries 2020), Mineral4EU (Minerals Intelligence Network for Europe (Minerals4EU) 2020), Euromines (Euromines 2020)

\begin{tabular}{llll}
\hline Subsector & Production Mt & Production value M€ & \% of production value \\
\hline Dimensional stone & 9 & 10,000 & 21.7 \\
Industrial minerals & 180 & 14,000 & 30.4 \\
Aggregates & 2700 & 15,000 & 32.6 \\
Metallic minerals & 800 & 7000 & 15.2 \\
Total & 3689 & 46,000 & 100 \\
\hline
\end{tabular}

But even though Europe has one of the best heavy machinery industries and manufactures and sells around a quarter of the world's mining equipment (Table 3 ) and is, in particular, at the forefront of the technological development in underground

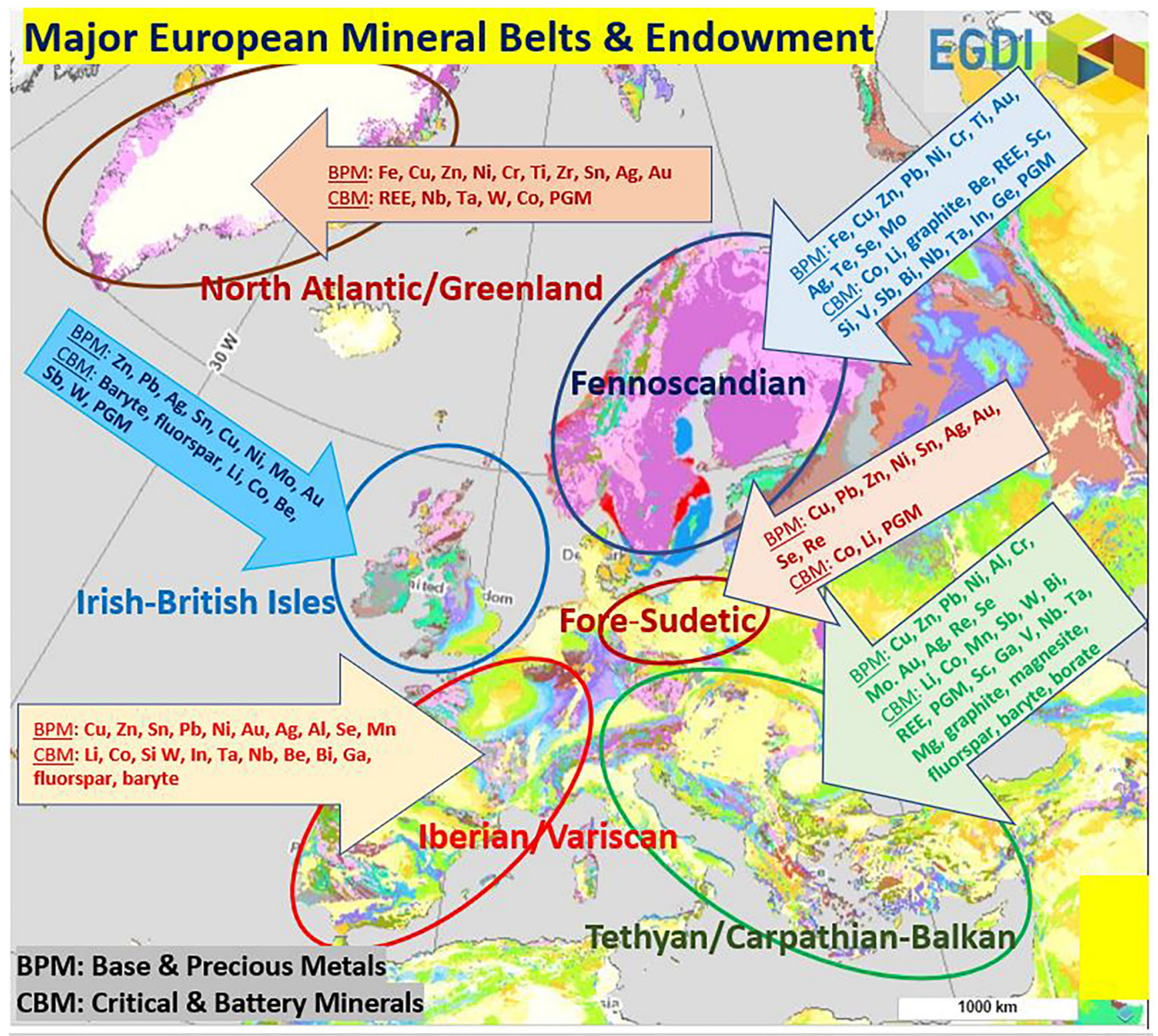

Fig. 6 Major European Mineral Belts \& Endowment. Source: Compiled from the Eurogeosurveys European Geological Data Infrastructure (EGDI) (EGDI 2020) by Nikos Arvanitidis 
Table 3 Top 10 largest heavy equipment manufacturers in the World 2018 (BCC Research 2017 2020)

\begin{tabular}{ll}
\hline Manufacture & 2017 sales \\
\hline Caterpillar (USA) & $\$ 26.6$ billion \\
Komatsu (Japan) & $\$ 19.2$ billion \\
Hitachi (Japan) & $\$ 8.3$ billion \\
Volvo CE (Sweden) & $\$ 7.8$ billion \\
Liebherr (Switzerland) & $\$ 7.4$ billion \\
XCMG (China) & $\$ 7.0$ billion \\
\hline
\end{tabular}

mining equipment, with leading Scandinavian companies such as Sandvik and Atlas Copco, both of Swedish origin, and has been for decades a leader in drilling and blasting technology, it can only produce around $40 \%$ (in volume) of the raw materials it needs.

\section{Implemented policies and strategies}

\section{Raw materials initiative: proposals and results}

Europe has addressed the problem of raw material supply (probably triggered by the metal prize hikes in 2003-2008) with the now famous Raw Materials Initiative (RMI) (European Commission 2008) introduced in 2008. The initiative established an integrated strategy to respond to the different challenges related to access to non-energy and nonagricultural raw materials. The initiative was based on three props:

1. Fair and sustainable supply of raw materials from global markets, ensuring an access to resources in third countries.

2. Fostering sustainable supply of raw materials from European sources

3. Boosting resource efficiency and supply of secondary raw materials through recycling

Additionally, the EU, through its various instruments and agencies, has supported the mining sector and its stakeholders. For example, the Horizon 2020 call and the 7th Framework program has been funding more than 2500 projects on raw materials (European Commission 2020a), covering technical, social, policy and governance aspects of mining.

Of particular interest is the European Innovation Partnerships on Raw Materials (EIP 2007) which is a stakeholder platform that brings together representatives from industry, public services, academia and NGOs and provides guidance to the European Commission, EU countries and private actors on innovative approaches to the challenges related to raw materials. The EIT brings together 115 partners from
$22 \mathrm{EU}$ countries, making it the biggest consortium of this kind in the world. The EIP launched its strategic implementation plan (SIP) in 2013 and has now 123 raw material commitments (voluntary joint undertakings that commit to implementing the SIP's actions and targets), which include around 980 unique partners from more than 50 different countries and have an indicative budget of close to $€ 2$ billion. Hopefully, they will deliver tangible results such as innovative actions or pilots, strategic documents or knowledge sharing activities. The European Commission has directed more than $€ 200$ million of R\&I funding to 37 projects dealing with raw materials through the Horizon 2020 program. The EIT applied for approximately $€ 400$ million in EU funding, a sum they commit to leverage by a factor of four over the period 20152022.

On the Global scenario, there are a great number of multistakeholder and international initiatives related to the resources global problem such as the Intergovernmental Forum on Mining, Minerals, Metals and Sustainable Development (IGF 2015), the World Resources Forum (WRF 2011), the World Materials Forum (WMF 2015), the OECD Policy dialogue on Natural Resource based Development (OECD 2013), the WEF's Responsible Mineral Development Initiative (The World Economic Forum's (RMDI) 2011) and a long list of other.

But it seems that all the considerable effort made by the EU has not yet succeeded in its main goals. We have not seen that the EU has gained access to resources in third countries, the raw materials' internal production has not raised and only the third pillar seems to be on the way thanks to the implementation of the circular economy. Three years after adoption, the Circular Economy Action Plan is fully completed. Its 54 actions have been delivered, even if the work on some of them continues beyond 2019 (European Commission 2019).

\section{The Strade project}

The EU project Strade Farooki et al. 2018) made a deep analysis of EU mineral production levels which showed that little progress has been made in increasing exploration expenditure in Europe and, at least for base metals, production is not expected to increase. They suggest a focused investor promotion strategy, whilst at the same time, there should be an improvement of the mining regulations in Member States a better access to geological data and dealing seriously with the issue of negative social perceptions around mining by EU citizens.

\section{MIN-GUIDE Project}

In the MIN-GUIDE project, one of the authors (Regueiro 2019) suggested a European policy towards defining mineral resources/sites of public interest or mineral extraction priority 
zones (as for example in the Austrian Mineral Resources Plan) and solid mineral planning systems which will avoid conflicts on the extraction permitting phase. The project also suggested accelerating the judicial times in which decisions are made can help speed up permitting times (e.g. good practice examples of quick resolution of appeals can be found in Flanders (Belgium) where the legal time-frames for the authorities to make decisions accelerate the outcomes and make it predictable for an investor to know when an appeal will be decided). A proposal is made of a specialized Land and Environment European Court of Justice. But overall suggests a one-stop shops from the exploration phase to avoid economic damages to the mining operators and the need to expand the Concessions Directive to non-energy minerals.

\section{The effect of policies: the aluminium case}

The circular economy has, in the case of some metallic ores, its own drawbacks. Aluminium production from bauxite ore is a high energy consumption process and the process leaves back a toxic red mud. Thus, the circular economy means that we will recycle as much elaborated aluminium as possible (tins, window frames, etc); the new products from this source will cost less. But as pointed out by Jesús Ramos Martín (Ramos Martín 2015), it looks as if growth could be unlimited as we will recycle residues and produce new resources. But then thanks to the new supply from recycling, we will need less aluminium ores. We are here faced with the Jevons paradox (Jevons 1865), which states that an improved efficiency will lower the price of the commodity; thus, the use of the resource will increase.

In the paradigmatic case of aluminium, we can see in Fig. 7 (Word Aluminium 2020) that aluminium has had a steady mining production growth during the 1960s, and, in the case of Europe, there has not been a production reduction, even though recycling level has increased.

Figures 8 and 9 show the aluminium cycle change between 1962 and 2018

Even though aluminium recycling has grown from 1962 to 2018 around $2000 \%$ from $250,000 \mathrm{t}$ to $5.3 \mathrm{Mt}$ and such increase should have produced a direct reduction of the production of primary aluminium (from mining operations and imports), this has not happened. Aluminium mining production has gone from 1.02 to $4.1 \mathrm{Mt}$, this means a growth of $4000 \%$. European aluminium production was $1.49 \mathrm{Mt}$ in 1962 and dropped to $519,000 \mathrm{t}$ in 2018 ; this meant a reduction to $1 / 3$ of the aluminium production from European sources, which represented 63\% in 1962 and dropped to $3 \%$ in 2018, as seen in Table 4.

Figure 10 shows that the cycle of aluminium in 2018 in China is similar to the European in 1962, with a small difference between production and imports of primary minerals. This shows that China is an industrialized economy but in a development phase, as was Europe in the 1960s.

The availability of cheap aluminium made it a more competitive metal; this produced a sharp increase in the investments in aluminium products (i.e. aluminium tins substituting glass bottles) resulting in a higher aluminium demand, thus accomplishing the Jevons paradox. A continuous growth in a circular economy framework might result in the effect contrary to the desired. The increase in aluminium demand produced a growth in the primary bauxite sources production, but as European sources are more expensive, due to the environmental and social restrictions, this limits the competitiveness of European sources forcing them either to foreclosure or to delay the opening of new operations. At the same time, this made imports more competitive, as Figs. 10 and 11 and Table 4
Fig. 7 Total for 1973 to 2020 : $1,327,561$ thousand metric tons of aluminium, source: World Aluminium (2020)

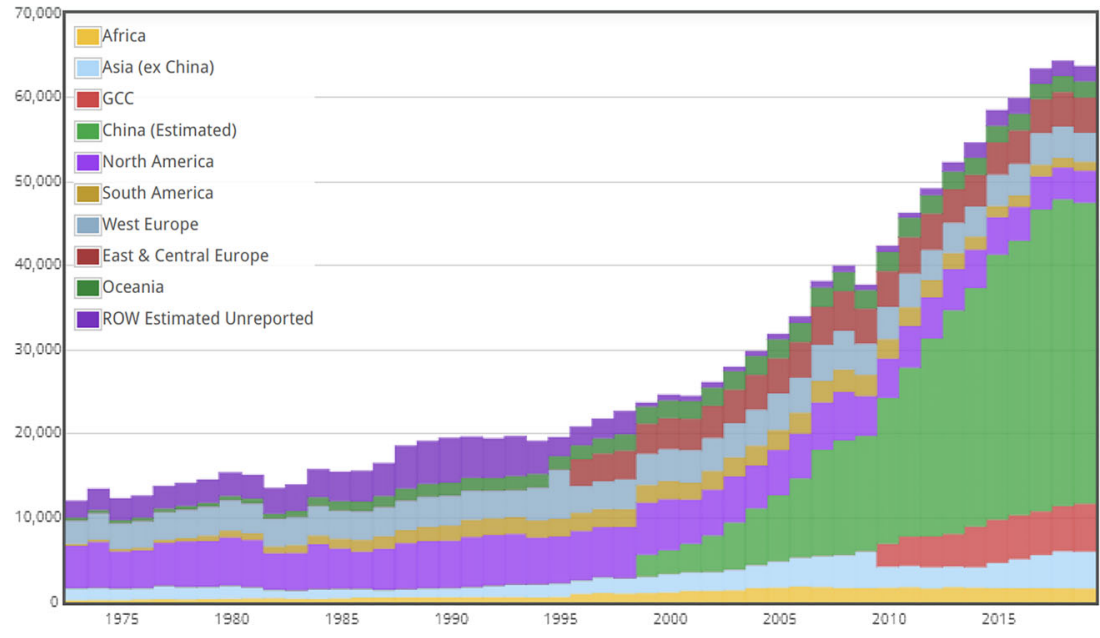




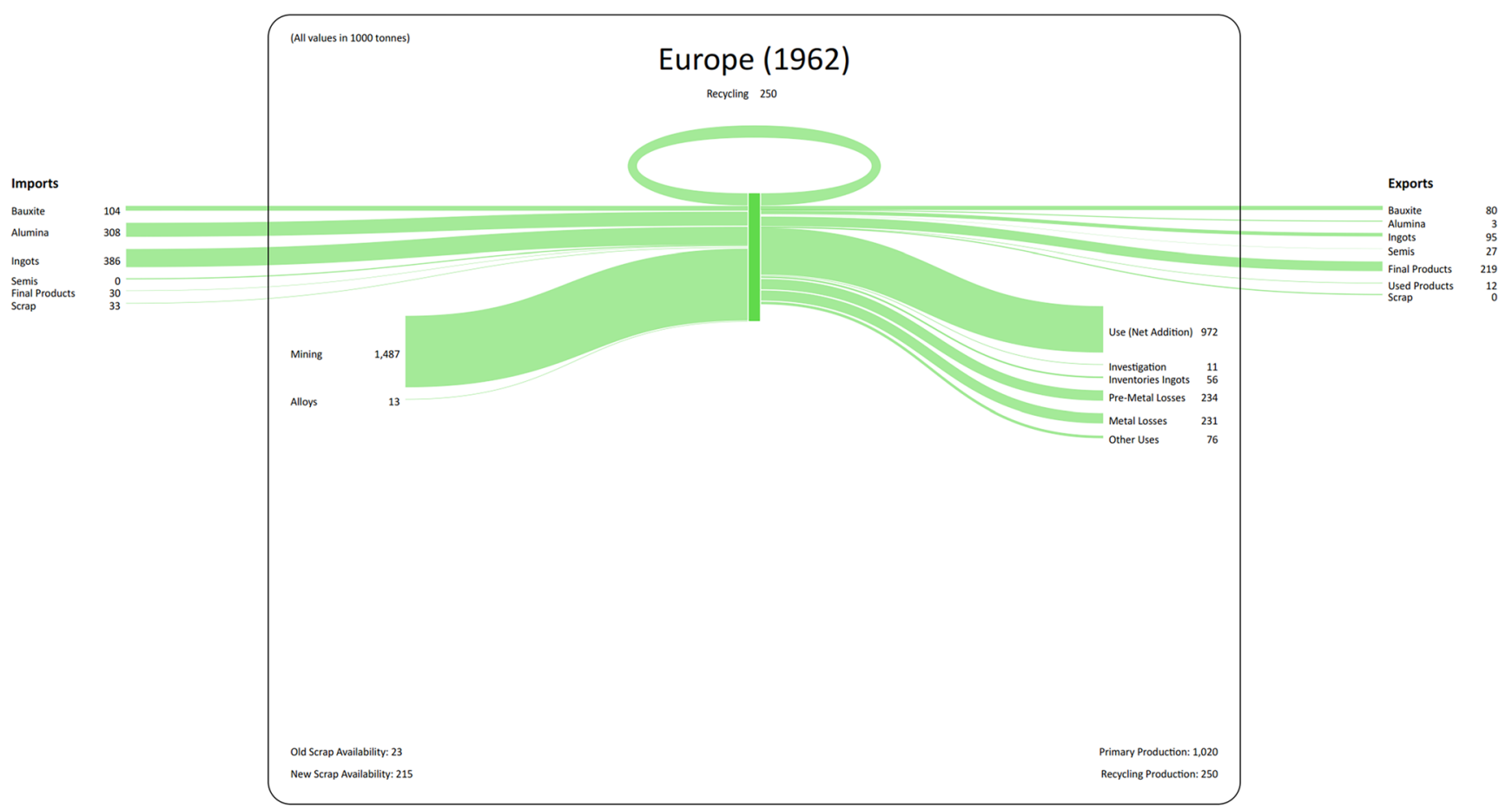

Fig. 8 Aluminium imports, exports, domestic production, recycling, use and losses in Europe in 1962. Source: World Aluminium (2020)

show. According to the USGS (2017), bauxite resources are estimated to be from 55 to 75 billion tons, in Africa (32\%), Oceania (23\%), South America and the Caribbean (21\%), Asia (18\%) and elsewhere, including Europe (only
$6 \%$ ). The EU bauxite production has also suffered from this problem, and a sharp $18 \%$ reduction has been observed in 2018 (Fig. 11). It takes 4 to $5 \mathrm{t}$ of bauxite to produce $2 \mathrm{t}$ of alumina, yielding $1 \mathrm{t}$ of aluminium.

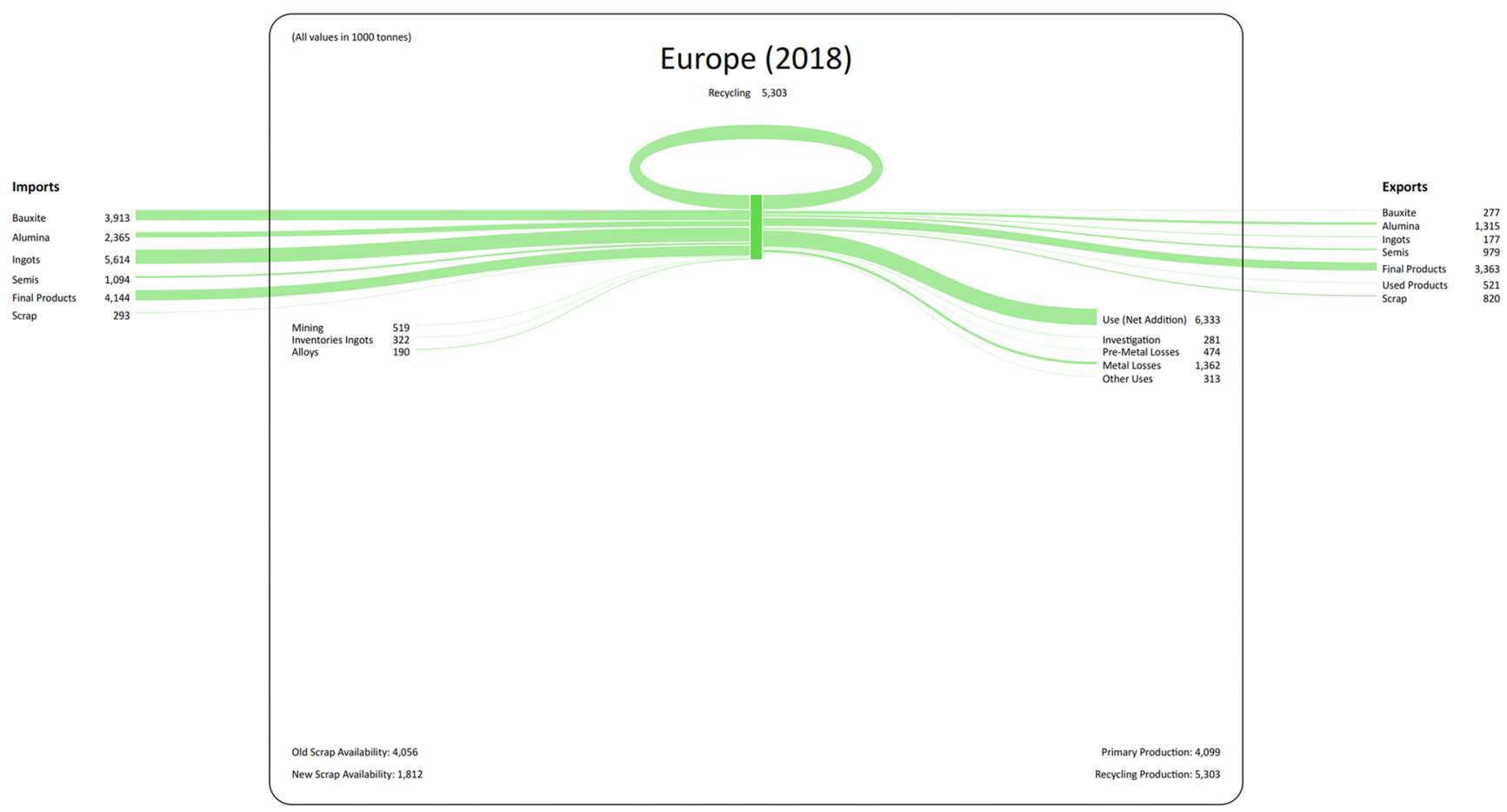

Fig. 9 Aluminium imports, exports, domestic production, recycling, use and losses in Europe in 2018. Source: World Aluminum (2020) 
Table 4 Sources of aluminium in Europe (kt). Source: World Aluminium (2020)

\begin{tabular}{|c|c|c|c|c|c|}
\hline 1962 & Imports & Europe & 2018 & Imports & Europe \\
\hline $\mathrm{Al}$ from bauxite & 104,00 & $1.487,00$ & Al from bauxite & $3.913,00$ & 519,00 \\
\hline $\mathrm{Al}$ from alumina & 308,00 & & Al from alumina & $2.365,00$ & \\
\hline $\mathrm{Al}$ in ingots & 386,00 & & $\mathrm{Al}$ in ingots & $5.614,00$ & 322,00 \\
\hline Other $\mathrm{Al}$ & 63,00 & & Other Al & $1.387,00$ & 119,00 \\
\hline \multirow[t]{2}{*}{ Subtotal } & 861,00 & $1.487,00$ & $\mathrm{Al}$ products & $4.144,00$ & \\
\hline & & & Subtotal & $17.423,00$ & 960,00 \\
\hline Total & & $2.348,00$ & TOTAL & & $18.383,00$ \\
\hline$\%$ of production & & $63 \%$ & $\%$ of Production & & $3 \%$ \\
\hline
\end{tabular}

The Green Deal: Europe need of mineral raw materials for its circular economy and sustainable development plan

The Green Deal (Fig. 12) is an all-inclusive set of policy initiatives by the European Commission with the overarching aim of making Europe climate neutral, such as energy transition, circular economy, resource efficiency; the deal is one of the six priorities for the new Commission for the next 5 years:

1. The fight against the climate change with the objective of turning Europe in the first climatically neutral continent.

2. An economy working for persons to promote social projects resulting an impulse for prosperity

3. A digital Europe empowering persons and promoting technologies
4. Promoting the European way of life and building an equal opportunities EU

5. A stronger Europe in the World, a global leader

6. An impulse to the democracy, protecting and strengthening it

The EU Green Deal pretends a clean economy, with zero emissions protecting the natural environment to improve the well-being of the people of the companies and which will lead the climate action in the whole planet.

This will produce an important change on the mineral resources industry, as it will affect the way building are made as well as to the building renovation sector. Energy and construction minerals will be the most affected mineral fields, since metallic minerals are already included in the circular economy, with different degree of success.

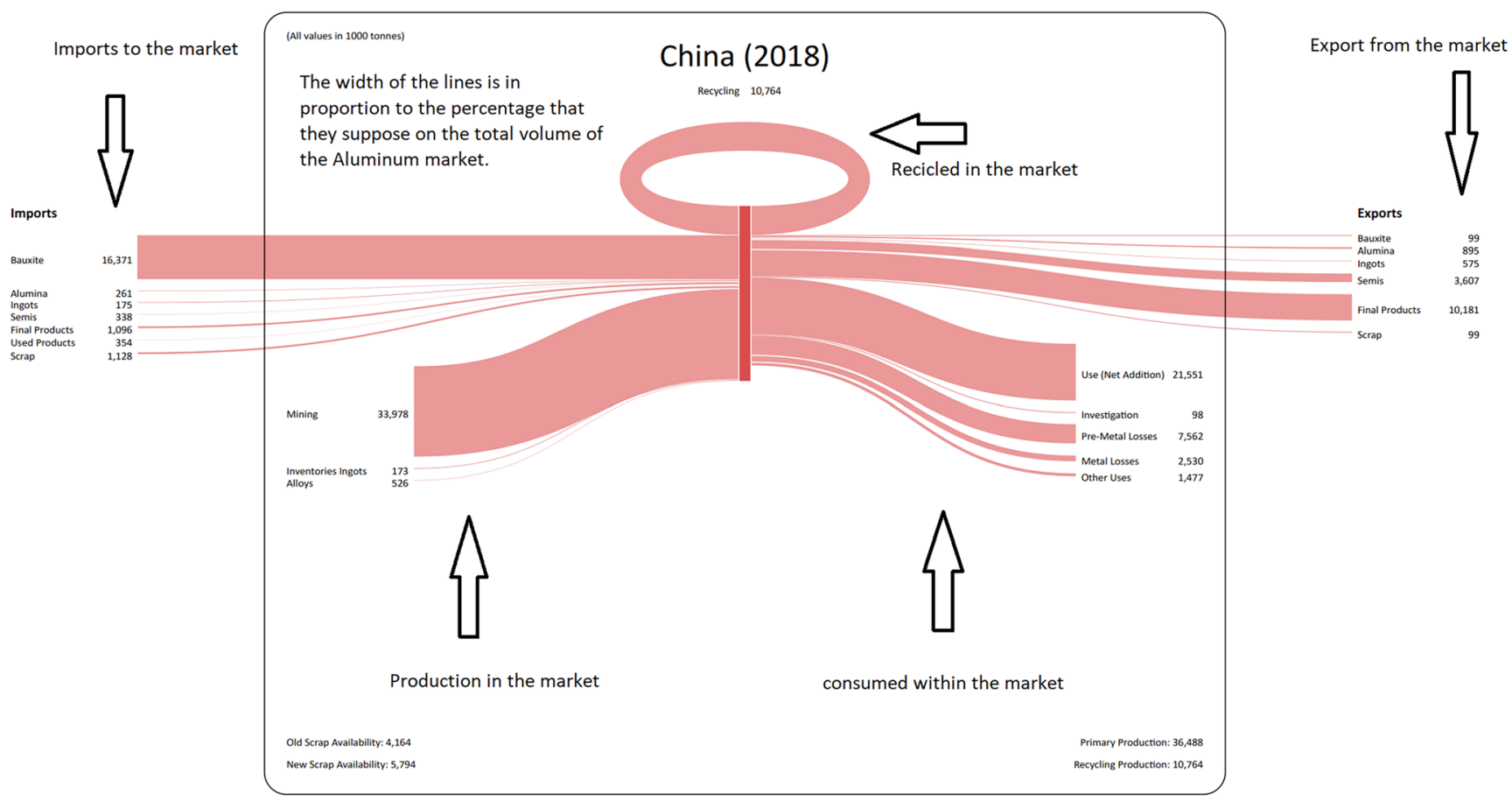

Fig. 10 Aluminium imports, exports, domestic production, recycling, use and losses in China in 2018. Source: World Aluminium (2020) 


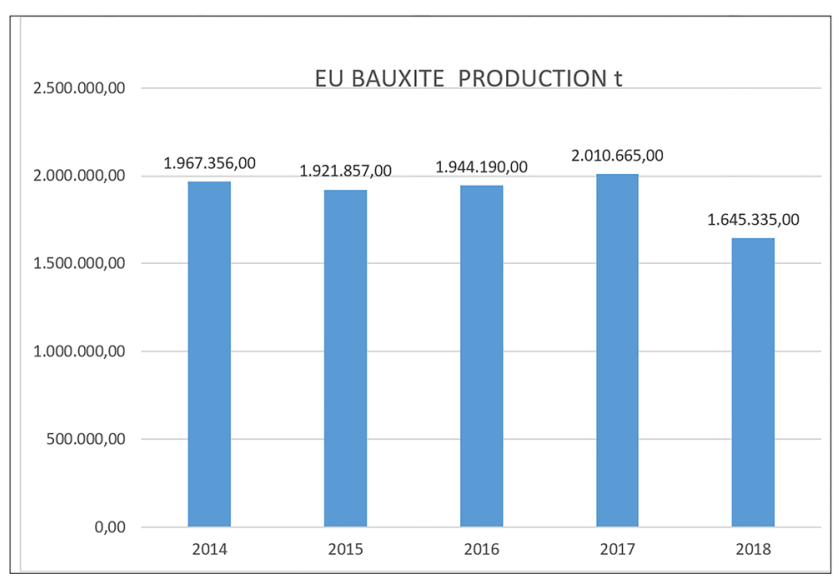

Fig. 11 EU bauxite production. Source: BGS

Building construction and renovation will require significant quantities of energy and mineral resources (such as sand and gravel or cement raw materials). At the same time, buildings represent $40 \%$ of the energy consumed globally but the so much needed energetic renovation rate of the real state varies from 0.4 to $1.2 \%$ in the EU states. Such a rate should be at least doubled to reach the climatic objectives and energy efficiency of the EU. But with the problem of increasing costs of recycling and the new requirements to open new aggregates operation in the EU, this might result in another case of the Jevons paradox, making more profitable importing such resources than producing them locally.

The Green Deal will also need a CRM EU-based industry. For this firm authorization, decision-making and permitting procedure will be needed, if EU stakeholders are really interested and committed to develop and use climate-smart technologies, and to make the energy transition happen. In this respect, to consider also the long period of time (from exploration to mining takes about 15 years) needed for the CRM value chains to be fully operational, the technologies addressing the implementation plan of climate change goals might not always readily available due to lack of the mineral resources needed. Finally, the Green Deal mineral demand should also address sustainability issues such as responsible sourcing, ethics and geopolitics.

\section{New industrial strategy for Europe}

The strategy, presented in March 2020, aims to drive Europe's competitiveness and its strategic autonomy at a time of moving geopolitical plates and increasing global competition. It will provide skills for industry (a fundamental pillar for the future of mining in Europe as the development of the Horizon 2020 project INTERMIN is proving (Alonso-Jiménez et al.

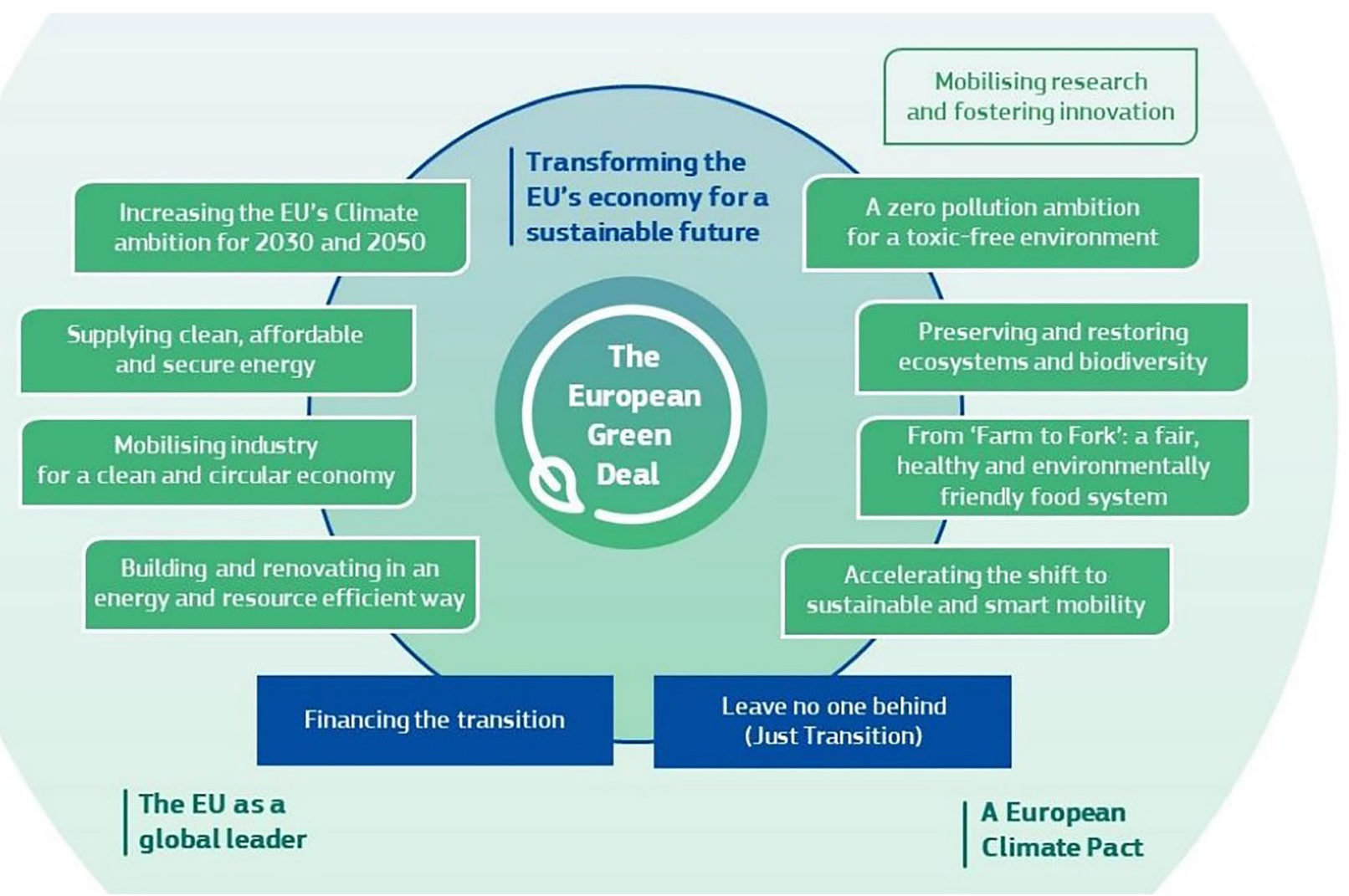

Fig. 12 The European Green Deal. Source: European Commission 
2020) by improving the quality and relevance of training and education, making skills more comparable, and easing the recognition of qualification, facilitate access to finance for innovative ideas via the Investment Plan, Horizon 2020 and COSME, promote entrepreneurship, support workplace innovation, empower citizens and communities with social innovation, revitalize EU regions, support digital transformation of European Industry, promote energy and resourceefficient technologies, support the development and uptake of Key Enabling Technologies such as new biomaterials, metals, polymers and advanced manufacturing, boost industry uptake of space data and promoting high level industrial dialogues (Industry 2030 High Level Industrial Round table, Strategic Forum for Important Projects of Common European Interest, Transformation of EU energy intensive industries for a climate neutral economy by 2050). All these plans will no doubt affect the mining industry in particular in skills, technology and energy consumption.

\section{Other future EU plans that affect mining}

The above and other policies and strategies (The Master-plan for a Competitive Transformation of EU Energy-intensive Industries Enabling a Climate-neutral; Circular Economy by 2050, Strengthening Strategic Value Chains for a futureready EU industry - report of the Strategic Forum for Important Projects of Common European Interest; Sustainable finance; EU principles for sustainable raw materials; EU COVID-19 recovery plan; UN Sustainable Development Goals) would need to be addressed by the new EIP SIP headline topics and covered by Horizon Europe thematic clusters as far as up-to-date mineral raw materials related R \& I efforts' concern. Most of the mineral raw material potential actions have been placed mainly in the cluster "Digital, Industry and Space", targeting manufacturing technologies, advanced materials, circular industries, emerging enabling technologies, artificial intelligence and robotics and low-carbon and clean industry.

The post-COVID era in the global mining industry

In previous chapters, we have reviewed the prognosis for the mining industry before COVID-19, but what we have already seen in the real world in the last 6 months is a sharp reduction in the prices of some commodities (Fig. 13).

This obviously is marking the pace of what might happen in 2021.

Simon M. Jowitt (Jowitt 2020) made a recent and detailed analysis of the potential COVID-19 pandemic effects on global mining. He concluded that out of the two potential scenarios envisaged: supply chain disruption or a slower demand growth, the data analysed points to a slower demand growth scenario. His prognosis was based in facts such as that both production and manufacturing has sharply dropped due to the

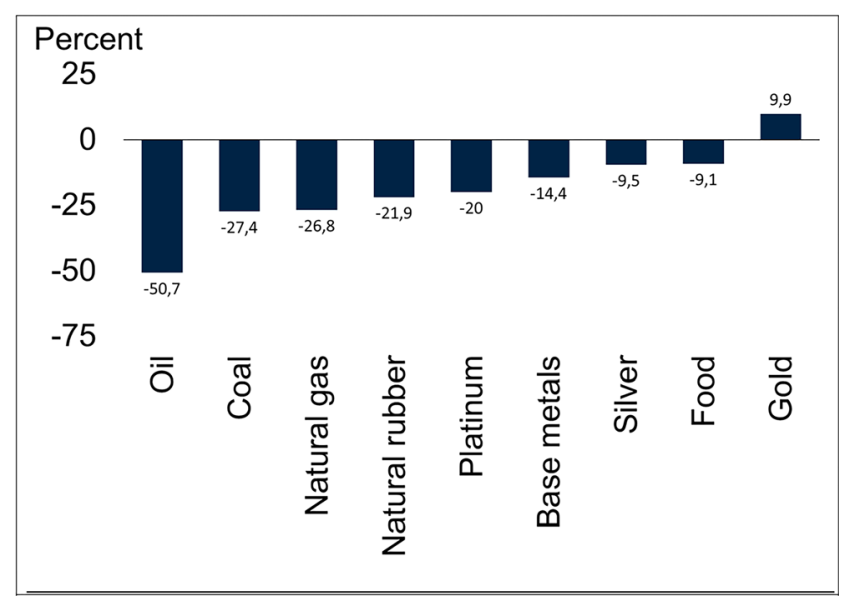

Fig. 13 Commodity price changes since January 2020. Source: Word Bank

economic deceleration caused by the efforts to reduce the COVID-19 propagation.

The United Nations predicted an economic downturn that will produce a global drop of the GDP of at least $1 \%$ (UNDESA 2020) and the International Monetary Fund has recently reported a prediction of a global economic growth of $-4.9 \%$ in 2020 (International Monetary Fund 2020). Such effects are even better displayed by the industrial production drop of the USA (Indexed to $2012=100$ ) from 109.1 in January 2020 to 92.6 in April 2020, a contraction of approximately by $15 \%$ (Board of Governors of the Federal Reserve System (US) 2020). Such reduction in industrial production was matched by a sharp increase in unemployment in the USA from $3.6 \%$ in January 2020 to $14.7 \%$ in April 2020 (U.S. Bureau of Labor Statistics 2020). Even though some of these statistics refer exclusively to the USA, similar impacts are observed all around the World.

A global downturn in the economy means a reduction in the manufactured goods and, in turn, a negative impact in the demand of minerals. Such reduction in demand will, no doubt, produce an oversupply of metals and a corresponding drop in metal prices. Oil prices have also dropped significantly more than metal prices during the COVID-19 crisis.

(Govreau 2021), in its Global Mining Investment Outlook, points out that at the end of 2020, the number of mining industry investment projects affected by the pandemic exceeded 1600 (accounting for US\$212 billion) according to enquires made by Industrial Info. Around $66 \%$ of these funds were for mining projects, and the rest was for processing and smelter projects. The good news is that most of these projects will not be cancelled but delayed from 3 to 18 months, and that the development of these projects will be advanced to 2021-2022.

All this reflects two main factors: a reduction of the demand during the economic deceleration related to COVID19 (that is, the same effect observed in metals prices) and 
the effect of the decision of Saudi Arabia and Russia not to reduce oil production, creating an excess of offer. Similar effects could be seen in the metal markets if stocks keep piling up (Fig. 14). Such situation of stock piling means that production is not yet affected by COVID-19 and prices drop. But this scenario might generate clashes between producing countries whose economies depend on the same metal (i.e. Democratic Republic of Congo, Zambia and Chile in the case of cooper).

It is thus difficult to quantify the negative impacts in the global mining industry in the long run by the COVID-19 pandemic because we do not know yet the future development of the pandemic and the resulting overall global recession. It is not adequate to make long-term predictions based in historical events such as the Great Depression and the Global Financial Crisis (GFC) of 2008, as those events were caused by economic factors and not by a global pandemic. If we are to make predictions, the global pandemic is probably similar to a $\mathrm{WW}$, as both result in a reduction of the global working human force and thus a reduction on the global capacity to spend in consumer goods. Such a situation, up until the availability of a vaccine, might have a severe and continual influence on the global economy during a certain time, as was the case of the WWs.

Nevertheless, COVID-19 pandemic might have some long-term positive effects in the mining if, as some forecast, there will be a V-shaped reaction in global GDP growth. This will increase investment in infrastructures, capital equipment and transportation as well as in lasting consumer goods. This obviously will immediately mean a high mineral and metal demand and a sharp rise in prices. Current efforts to stimulate national production both in the USA and in Europe might also contribute to increase mining production in those regions.

In conclusion, any long-term positive effect in the mining industry by the COVID-19 pandemic should be observed under the light of the potential negative short-term impacts that might affect part of the mining industry, which might not survive to see the long-term benefits.

\section{Conclusions}

Before COVID-19, the expected behaviour of the mining sector globally pointed to a rising production trend in the six resource-rich developing countries, a stable situation in current production leaders (Australia, Canada, China and Russia) and a stable drop in the EU. EU research projects such as FORAM suggested that on a long-term basis, the global demand for metals was expected to remain robust. INTRAW also previewed a rising overall demand of nearly $500 \%$ at least for certain minerals especially concentrated in energy storage technologies, although also enhanced the existence of social and environmental risks of their model. The WEF also forecasted a steady growth of mining in the World and in 2050, in line with GDP global growth. They think that by 2050, the circular economy will become the norm in large advanced economies, thanks to series of reforms that focus on increasing sustainability, not just in the raw material industry. Meeting the challenge of large-scale renewable energy deployment will require the constant availability of a variety of key minerals, as well as stable prices and minimal market disruption. Recycling, reuse and renovation will play an important role in limiting and meeting future demand for minerals for clean energy.

To make this pre-COVID forecasts, we needed reliable mining statistics, but it seems that such figures are not either consistent or available, unless you want to pay private companies for the information. In 1995, the EU Commission published a first edition of a European Mineral Yearbook (https:// op.europa.eu/en/publication-detail/-/publication/7486a011e223-4733-91d9-f2617f19452b), the first edition prepared by ROSKILL Ltd with data of 1993 and the second was prepared by the BRGM with data of 1995, but this was later discontinued. The last mining statistical effort by the Commission was the MINERALS4EU project (http:// minerals4eu.brgm-rec.fr/m4eu-yearbook/index.html) with data of 2018. The fact that the EU Commission is deploying
Fig. 14 London Metal Exchange (LME) copper, zinc and nickel stocks (i.e. quantities of metal within the LME warehouse system, shown as dashed lines) and prices (shown as solid lines) compared with key COVID-19 events. Source: Jowitt (2020)

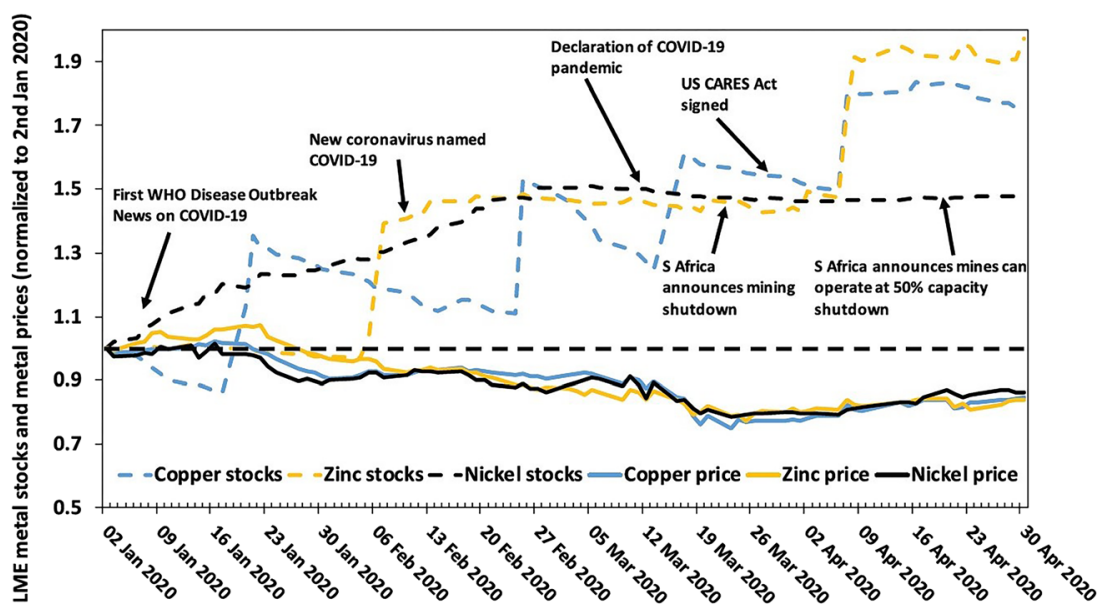


the RMIS (https://rmis.jrc.ec.europa.eu/ RMIS) through the Joint Research Centre (JRC) means that for the Commission free accessible data is important and that Europe needs the mining information in its long-term planning. This is not happening today.

Although it is very clear from the information included in this paper that Europe has a great mineral potential not yet exploited, and although Europe has one of the best mining industries and manufactures and distributes around one fourth of the global mining equipment, it can only produce around $40 \%$ in volume of the raw materials it needs.

The reaction of the Commission to these facts was then the launch of the Raw Material Initiative. But it seems that all the effort made by the EU has not yet succeeded in its main goals. We have not seen that the EU has gained access to resources in third countries, the raw materials' internal production has not raised, and only the third pillar seems to be on the way thanks to the implementation of the circular economy, in fact 3 years after adoption, the Circular Economy Action Plan is fully completed and its 54 actions have been delivered, even if the work on some of them continues.

But as the STRADE project has proven, very little progress has been made in increasing exploration expenditure in Europe and, at least for base metals and at the same time, the MIN-GUIDE project has proposed a specialized Land and Environment European Court of Justice and a one-stop shops from the exploration phase to avoid economic damages to the mining operators and the need to expand the Concessions Directive to non-energy minerals.

In fact, we have also revealed here that some of the policies implemented might result in exactly the opposite effect to the intended, as the aluminium Jevons paradox has clearly shown. A continuous growth in a circular economy framework, resulted in an increase in the aluminium demand, produced a growth in the primary bauxite sources production, but as European sources are more expensive, due to the environmental and social restrictions, this limited the competitiveness of European sources forcing them to closure or delaying the opening of new operations and finally resulting in a sharp drop of the EU bauxite production.

The Green Deal, when implemented, will affect the way building are made as well as to the building renovation sector, since it will require significant quantities of energy and mineral resources (such as sand and gravel or cement raw materials). Also, the so much needed energetic renovation rate should be at least doubled from current figures to reach the climatic objectives and energy efficiency plans of the EU.

During COVID-19, the WB has evidenced sharp drops in mineral commodity prices all around the globe.

After COVID-19, all predictions point to a fall in the global GPD around 5\%. This means that the pandemic will have a profound impact in the European mining, at least in
2020 , but we expect a sharp recovery in 2021, in agreement with the World Bank GDP evolution predictions but any long-term positive effect in the mining industry by the COVID-19 pandemic should be observed under the light of the potential negative short-term impacts that might affect part of the mining industry, which might not survive to see the long-term benefits. Goldman Sachs in a recent forecast (Goldman Sachs 2020) expects a structural bull market emerging for commodities in 2021. After the crisis, and once recovered, the EU will face a "back to business" trend in mining, and this means a smooth production reduction at least until 2023. Looking at the famous Raw Materials Initiative, we can see that the only well-developed pillar is the circular economy, which is slowly inflowing in the European culture. This in itself means a reduction in energy consumption and a rationalization of its use. This is always easier to implement at a time like this of crisis, and not in an expansive phase where reducing productivity always generates a loss of profit. Starting from a low point where the improvement in efficiency implies an increase in sustainability and at the same time a greater profit, this will be easier now than once the normal rhythm of mining productivity has been recovered. To recover the pace, the EU must be very careful with the national members mining and environmental policies, which are posing a clear risk of transferring their national social and environmental burden of mining to third countries. The EU must have a strong domestic mining sector, which must adhere to the highest social and environmental standards to avoid such transference. Maybe, in view with the Chinese-USA current state of relations, it is the time for the EU to reach bilateral agreements about the EU's supply from China, and at the same time, include in the agreement the need of responsible mining practices of Chinese companies abroad.

Europe has a wealth of potential mineral resources to exploit, but there is a need of a European view on the whole mining cycle, from exploration to reclaimed foreclosure. Maybe it is time for an EU Mining Agency, as suggested by Ericsson, M. (RMG) in 2012 (Engineering and Mining Journal 2012) an idea also included in the Proposal for an official regional mineral strategy from 2012 for the two northern most regions in Sweden (Norrbotten and Västerbotten) (Regional workshop on mining startegy. 26 April 2012. Skellefteå, 2012) and later in 2013 (Northern Engineering 2013), and more recently by the MIN-GUIDE (2019) project. Such agency could channel the immense variety of interests involved and serve to the purposes of the Green Deal, maintaining the EU mining-tech companies in a competitive European mining sector to keep their EU global lead in resource-efficient and environmentally friendly mining technology, favour and increase in exploration expenditure-a key for the EU mining of the future - and design and promote best practice principles for mining regulations in the EU 
Member States. The agency could also produce best practice rules, design mining policies and its exchange between members and assist them to choose the appropriate tools for achieving their own mining policies. It could also, as have suggested the STRADE project, design a Mining Rights Management System and a One-Stop-Shop for investors, as the first step for exploration and mining companies seeking to identify potential projects. The agency could also create citizen awareness campaigns to improve public perception of mining and design and support innovation activities for the mining sector using the EU funding schemes. If nothing is done, the EU will in 30 years close all its mining operations and transfer the problem to other parts of the world. Let us hope we do not allow this to happen.

\section{References}

Alonso-Jiménez A, Regueiro y González-Barros M, Elorza Tenreiro F, Correia V (2020) INTERMIN (International Network of Raw Materials Training Centres). Eur Geol 50:78-82. https://doi.org/10. 5281/zenodo.4311728

BCC Research 2017 (2020) Construction machinery manufacturing: global markets to 2020. Reportlinker.com. Retrieved from https:// www.reportlinker.com/p05257943/Construction-MachineryManufacturing-Global-Markets-to.html

Board of Governors of the Federal Reserve System (US) (2020) Industrial Production Index [INDPRO], retrieved from FRED, Federal Reserve Bank of St. Louis. Retrieved from https://fred.stlouisfed. org/series/INDPRO

British Petroleum (2019) 68th edition of the BP Statistical Review of World Energy 2019.

EGDI (2020) European Geological Data Infrastructure. Retrieved from http://www.europe-geology.eu/

EIP (2007) European Innovation Partnerships on Raw Materials. Retrieved from https://ec.europa.eu/growth/sectors/rawmaterials/eip en

Northern Engineering (2013) Northern Engineering. Int Min 8(11):82

Engineering \& Mining Journal (2012) "Nordic mining hits new heights" in Leading Developments. Eng Min J (9). Retrieved 1 30, 2021, from https://www.e-mj.com/news/leading-developments/nordicmining-hits-new-heights/

Euromines (2020) Euromines. Retrieved from http://euromines.org

European \& International Federation of Natural Stone Industries (2020) European \& International Federation of Natural Stone Industries. Retrieved from https://www.euroroc.net/

European Commission (2008) Communication from the Commission to the European Parliament and the Council. The raw materials initiative - meeting our critical needs for growth and jobs in Europe. Retrieved from https://eur-lex.europa.eu/LexUriServ/LexUriServ. do?uri=COM:2008:0699:FIN:en:PDF

European Commission (2019) Report from the Commission to the European Parliament, the Council, the European Economic and Social Committee and the Committee of the Regions on the implementation of the Circular Economy Action Plan. Retrieved from https://eur-lex.europa.eu/legal-content/EN/TXT/?qid= 1551871195772\&uri=CELEX:52019DC0190

European Commission (2020a) Mining related projects funded by the Commission programs. Retrieved from https://cordis.europa.eu/ search/en?q=contenttype $\% 3 \mathrm{D} \% 27$ project $\% 27 \% 20$ AND $\% 20 \%$ 27 mining\%27)\&p=1\&num=10\&srt=Relevance:decreasing.
European Commission (2020b) Raw Materials Information System (RMIS). Retrieved from https://rmis.jrc.ec.europa.eu/

Farooki M, Hinde C, Lof A (2018) Strategic Dialogue on Sustainable Raw Materials for Europe (STRADE). Supporting the EU Mineral Sector Capitalising on EU strengths through an investment promotion strategy. Retrieved from http://stradeproject.eu/ fileadmin/user_upload/pdf/STRADE_EU_Mining_Sector_ Support_Sept2018.pdf

Federal Ministry of Industry Agriculture and Regions Ministry of Austria (2020) World Mining Data.

Freedonia (2016) World Construction Aggregates (Freedonia Focus Reports No. 3389)

GAIN (2020) Global Aggregates Information Network. Retrieved from https://www.gain.ie/

Goldman Sachs (2020) Commodities headed for bull market in 2021. Mining.com. Retrieved 130,2021 , from https://www.mining.

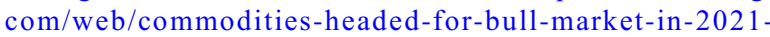
goldman-sachs/

Govreau JF (2021) Global Mining Investment Outlook. (S. Fiscor, Ed.). Eng Min J 222(1):24-29 Retrieved 2021, from https://www.e-mj. com/flipbooks/january-2021/?showpage=26

Hund K, La Porta D, Fabregas T, Laing T, Drexhage J (2020) Climatesmart mining facility. Minerals for Climate Action: The Mineral Intensity of the Clean Energy Transition. World Bank. Retrieved from http://pubdocs.worldbank.org/en/961711588875536384/ Minerals-for-Climate-Action-The-Mineral-Intensity-of-the-CleanEnergy-Transition.pdf

IGF (2015) Intergovernmental Forum on Mining, Minerals, Metals and Sustainable Development. Retrieved from https://www. igfmining.org/

Industrial Minerals Association - Europe (2020) Industrial Minerals Europe (IMA). Retrieved from https://www.ima-europe.eu/

International Monetary Fund (2020) https://www.imf.org/en/ Publications/WEO/Issues/2020/06/24/WEOUpdateJune2020. Retrieved from World economic outlook update, June 2020

INTRAW (2020) International Raw Materials Observatory. Retrieved from https:/intraw.eu/

Jevons WS (1865) The Coal Question: an enquiry concerning the progress of the Nation, and the probable exhaustion of our coal-mines.

Jowitt SM (2020) COVID-19 and the Global Mining Industry. SEG DISCOVERY, pp 33-42

Kose MA, Sugawara N, Terrones ME, Kose MA, Ohnsorge F (2019) What Happens During Global Recessions? Kose and Ohnsorge (eds)

Kose MA, Sugawara N, Terrones ME (2020). Global recessions

Minerals Intelligence Network for Europe (Minerals4EU) (2020). Minerals Intelligence Network for Europe (Minerals4EU). Retrieved from http://www.minerals4eu.eu/index.php

MIN-GUIDE (2019) Minerals Policy Guidance for Europe (MINGUIDE).

OECD (2013) Policy dialogue on Natural Resource based Development. Retrieved from http://www.oecd.org/dev/4.\% 20Scoping\%20paper.pdf

Ramos Martín J (2015) Base material de la economía del conocimiento. América Latina en Movimiento 507:8-10

Regional workshop on mining startegy (2012) Skellefteå. (2012). Proposal for an official regional mineral strategy from 2012 for the two northern most regions in Sweden (Norrbotten and Vaterbotten). Retrieved from https://docplayer.se/46125717-Regionalmineralstrategi-for-norrbotten-och-vasterbotten.html

Regueiro M (2019) How critical is the mineral supply in the EU? The legal framework dilemma

Regueiro M, Espi J (2019) The returns on mining exploration investments. Boletín Geológico y Minero 130(1):161-180 ISSN: 03660176. https://doi.org/10.21701/bolgeomin.130.1.010 
The World Economic Forum's (RMDI) (2011) WEF's Responsible Mineral Development Initiative.

Towards a World Forum on Raw Materials. FORAM Project (2017) D3.1 Global Raw Materials Policy Context Report. WP 3 - Strategic Planning

U.S. Bureau of Labor Statistics (2020) Unemployment rate [UNRATE] : Retrieved from FRED, Federal Reserve Bank of St. Louis. Retrieved from https://fred.stlouisfed.org/series/ UNRATE

UNDESA (2020) https://www.un.org/development/desa/dpad/wpcontent/uploads/sites/45/publication/WESP2020_MYU_Forecastsheet.pdf. Retrieved from World economic situation and prospects as of mid-2020: United Nations Department of Economic and Social Affairs, $2 \mathrm{p}$

Union Européenne des Producteurs de Granulats (2020) European Aggregate Association (UEPG). Retrieved from http://www. uepg.eu/

WMF (2015) World Materials Forum. Retrieved from https:// worldmaterialsforum.com/home.html
World Aluminium (2020) Alucycle in World Aluminium. Retrieved from https://alucycle.world-aluminium.org/public-access/

World Bank (2020) Global Economic Prospects. Chapter 1. Global Outlook. Pandemic, recession: The Global Economy in Crisis

World Economic Forum, in collaboration with Boston Consulting Group (2015) Mining \& Metals in a Sustainable World 2050. Retrieved from http://www3.weforum.org/docs/WEF_MM_Sustainable_ World_2050_report 2015.pdf

WRF (2011) World Resources Forum. Retrieved from https://www. wrforum.org/

Bolt J, Inklaar R, De Jong H, Van Zanden JL (2018) Rebasing 'Maddison': new income comparisons and the shape of long-run economic development. GGDC Research Memorandum,174:1-67

Publisher's note Springer Nature remains neutral with regard to jurisdictional claims in published maps and institutional affiliations. 